\author{
Д. П. Зылевіч, Н. У. Канапацкая \\ Беларускі дзяржаўны тэхналагічны ўніверсітэт
}

\title{
СТРУКТУРА, ЗМЕСТ І ФУНКЦЫ ЗАГАЛОВАЧНАГА КОМПЛЕКСУ ПЕРЫЯДЫЧНАГА ВЫДАННЯ (НА ПРЫКЛАДЗЕ ГАЗЕТЫ «ЗВЯЗДА»)
}

Мэта артыкула - выявіць і апісаць структуру загаловачнага комплексу грамадска-палітычнай беларускамоўнай газеты «Звязда». У цэнтры ўвагі аўтараў такія элементы загаловачнага комплексу, як рубрыка, падрубрыка, асноўны загаловак, унутраныя загалоўкі, лід, шапка. Прыведзены асноўныя патрабаванні да загалоўка, яго трактоўкі, ахарактарызавана найбольш распаўсюджаная структура загаловачнага комплексу «Звязды».

Аўтары артыкула прыводзяць прыклады загалоўкаў розных відаў, характарызуюць элементы загаловачнага комплексу з пункту гледжання аб'ёму: назвы рубрык найчасцей складаюцца 3 аднаго слова, падрубрык - з двух-трох, асноўны загаловак - гэта 4-6 слоў, падзагаловак звычайна даўжэйшы. Унутраныя загалоўкі матэрыялаў таксама не бываюць буйнымі. Найбольшы па аб'ёме і адпаведна найбольш інфарматыўны элемент загаловачнага комплексу - гэта лід.

Стылістыка загаловачнага комплексу газеты «Звязда» нейтральная, і гэта, як лічаць аўтары артыкула, у поўнай меры адпавядае мэтаваму прызначэнню (грамадска-палітычнае выданне) і чытацкаму адрасу газеты (дарослы чытач, які цікавіцца грамадскім і палітычным жыццём краіны). Асноўная функцыя загаловачнага комплексу гэтай газеты - інфармацыйная. Экспрэсіўна-ацэначная, рэкламная і функцыя пераканання праяўляюцца значна менш.

У заключэнні аўтары артыкула адзначаюць, што газета «Звязда» - гэта сучаснае перыядычнае выданне, якое развіваецца згодна з сусветнымі тэндэнцыямі ў перыёдыцы. Загалоўкі розных узроўняў, якія ўжывае газета на сваіх старонках, утвараюць гарманічны загаловачны комплекс.

Ключавыя словы: перыядычнае выданне, загаловачны комплекс, рубрыка, віды загалоўкаў, функцыі загалоўкаў.

Для цытавання: Зылевіч Д. П., Канапацкая Н. У. Структура, змест і функцыі загаловачнага комплексу перыядычнага выдання (на прыкладзе газеты «Звязда») // Труды БГТУ. Сер. 4, Принти медиатехнологии. 2021. № 2 (249). С. 98-103.

\author{
D. P. Zylevich, A. V. Konopatskaya \\ Belarusian State Technological University
}

\section{STRUCTURE, CONTENT AND FUNCTIONS OF THE HEADLINE COMPLEX OF A PERIODICAL EDITION (ON THE EXAMPLE OF THE NEWSPAPER “ZVYAZDA”)}

The purpose of the article is the identification and the description of the structure of the headline complex of the sociopolitical Belarusian-language newspaper "Zvyazda". The authors focus on elements of the headline complex: the heading, subheading, main heading, internal headings, lead, header. There are the main requirements for the headline, its interpretations and the characteristic of the most common structure of the headline complex "Zvyazda".

The authors of the article give examples of different types of headlines, characterize the elements of the headline complex in terms of volume: the names of headings most often consist of one word, subheadings - of two or three, the main heading is $4-6$ words, the subheading is usually longer. Internal headings of materials are also not large. The lead is the largest and the most informative element of the headline complex by volume.

The style of the headline complex of the newspaper "Zvyazda" is neutral, and this, according to the authors of the article, fully corresponds to the intended purpose (sociopolitical publication) and the reader's address of the newspaper (an adult reader interested in the social and political life of the country). The main function of the headline complex of this newspaper is informational. The expressive-evaluative, advertising and persuasion functions are less pronounced.

In conclusion, the authors of the article note that the newspaper "Zvyazda" is a modern periodical edition that develops according to world trends in periodicals. The headlines of various levels that the newspaper uses on its pages form a harmonious headline complex.

Key words: periodical, headline complex, rubric, types of headlines, functions of headlines.

For citation: Zylevich D. P., Konopatskaya A. V. Structure, content and functions of the headline complex of a periodical edition (on the example of the newspaper "Zvyazda"). Proceedings of BSTU, issue 4, Print- and Mediatechnologies, 2021, no. 2 (249), pp. 98-103 (In Russian). 
Уводзіны. Сучасны чытач перыядычнага выдання не схільны чытаць усю газету ўважліва, удумліва, ад першага да апошняга радка. У яго няма для гэтага ўстойлівага матыва. Найчасцей мы праглядваем выданне, выхопліваем 3 яго загалоўкі розных узроўняў, шрыфтавыя і каляровыя вылучэнні, фотаздымкі, спыняючыся на тых матэрыялах, якія падаліся нам цікавымі. Загалоўкі, а дакладней іх змест, стыль, лексіка, мастацкія і дызайнерскія прыёмы, арыентуюць нас у газеце, вызначаючы жаданне чытаць ці адкласці нумар у бок [1]. Загалоўкі розных узроўняў рэпрэзентуюць і дыферэнцыруюць газетны тэкст, вызначаюць алгарытміку чытацкіх дзеянняў.

Цяжка ўявіць, але яшчэ дзвесце гадоў таму назад матэрыялы ў газетах нярэдка друкаваліся без загалоўкаў. На сённяшні дзень журналісты і рэдактары, як правіла, не абмяжоўваюцца адным асноўным загалоўкам для публікацыі. Звычайна выкарыстоўваецца і падзагаловак. Як піша С. М. Гурэвіч, «звычайны загаловак дае першаснае ўяўленне аб тэме і змесце публікацыі. Падзагаловак - найчасцей тэматычны - удакладняе, паясняе, зрэдку развівае загаловак, які стаіць над ім» (тут і далей пераклад на беларускую мову наш - Д. 3.) [2].

Матэрыял можа пачынацца з ліда - гэта першы абзац, выдзелены графічна, які прадстаўляе апорны факт. Тэкст публікацыі можа мець унутраныя загалоўкі, якія адлюстроўваюць яго змест і структуру.

Над асноўным загалоўкам ці збоку ад яго можа ўказвацца рубрыка, яна звычайна характарызуе тэматычны блок матэрыялаў нумара, выступае ў якасці маркёра. Матэрыялы адной паласы ці яе часткі або цэлага разварота могуць быць аб'яднаны агульнай тэмай, тады яны аб'ядноўваюцца і агульным загалоўкам - шапкай. Асноўная задача шапкі - «прыцягнуць увагу чытача да падборкі матэрыялаў на актуальную тэму, кідка і сцісла выказаць агульны сэнс гэтых матэрыялаў» [3, с. 11].

Усе пералічаныя намі элементы газетнай публікацыі - загаловак, падзагаловак, унутраны загаловак, лід, шапка, рубрыка - утвараюць сабой загаловачны комплекс выдання, аналізу якога на матэрыяле газеты «Звязда» і прысвечаны дадзены артыкул.

Мэта артыкула - выявіць і апісаць структуру загаловачнага комплексу грамадска-палітычнай беларускамоўнай газеты «Звязда». Аб’ектам даследавання сталі нумары газеты за люты 2021 г., прадметам - элементы загаловачнага комплексу.

У рабоце выкарыстоўваюцца апісальны метад даследавання (назіранне, апісанне, супастаўленне), метад кампанентнага аналізу, рэдактарскі аналіз.

Актуальнасць аналізуемай тэмы абумоўлена недастатковай даследаванасцю сучасных падыходаў да праектавання газеты, якая б была канкурэнтаздольнай на фоне сучасных медыя і разнапланавых інтэрнэт-рэсурсаў. У гэтым сэнсе практыка апярэджвае тэорыю. Газетныя загалоўкі найчасцей з'яўляюцца прадметам даследавання філологаў, але рэдактары і журналісты таксама звяртаюцца да асэнсавання практычнага вопыту ў гэтым плане [4].

Метадалагічнай базай для нашага даследавання паслужылі працы В. С. Мужава, Э. А. Лазаравай, С. М. Гурэвіча, Д. Сурніна, Ю. А. Бяловай, Ж. А. Нікіфаравай, М. І. Шостака, Ю. В. Трубнікавай, М. А. Дрога, І. А. Сырова і інш.

Асноўная частка. Спачатку прывядзём азначэнне тэрміна «загаловак». С. М. Гурэвіч піша: «загаловак зараз уяўляе сабой арганічны першы элемент тэкставай публікацыі, непарыўна 3 ёй звязаны, больш за тое - выцякае з яе зместу» [2]. 3. А. Муталіева і 3. І. Дабрыева называюць загаловак «раўнапраўным элементам газетнага тэксту, уваходзячым у яго і ўзаемазвязаным з іншымі элементамі цэлага твора» [5, с. 46].

Прывядзём іншыя трактоўкі. П. М. Зекіева лічыць, што «імя тэксту ў гэтым выпадку разглядаецца спажыўцом інфармацы як нешта, што стаіць па-за творам, як самастойны твор газетнага жанру сам па сабе гатовы ў дастатковай ступені інфармаваць і аказваць уплыў» [6]. Ю. М. Фаткабрарава ў сваёй дысертацыі таксама піша, што загаловак газетных СMI - гэта самастойны, адасоблены элемент сістэмы, «семантычна, прагматычна і функцыянальна звязаны 3 тэкстам паведамлення, але стаіць па-за ім» [7, с. 19].

Значыць, з аднаго боку, загаловак з'яўляецца структурным элементам газетнага тэксту, а 3 другога - гэта самастойны твор. 3 улікам таго, што сучасны чытач не адразу і не заўсёды чытае газету ад першага да апошняга радка, а «выхоплівае» 3 яе загалоўкі, вызначаючы, што будзе чытаць, то можна сказаць, што зараз узмацняецца тэндэнцыя да другой трактоўкі загалоўка. У сувязі з гэтым журналісты часцей выкарыстоўваюць загалоўкі, якія супастаўляюцца тэксту, выклікаюць адпаведныя асацыяцыі, а не з'яўляюцца квітэсэнцыяй яго зместу: «найбольш прадуктыўны тып у публіцыстыцы сёння - інтрыга ў загалоўку» [8, с. 125]

А. В. Калеснічэнка ў сваім вучэбным дапаможніку па практычнай журналістыцы прыводзіць такія патрабаванні да газетнага загалоўка. Загаловак павінен быць ясным выказваннем, заключаць асноўную ідэю тэксту, не супярэчыць зместу матэрыялу, быць карэктным, зразумела сфармуляваным, выклікаць цікавасць у чытача [9, с. 97]. Акрамя таго, загаловак адлюстроўвае пазіцыю выдаўца, ці сацыяльнай групы, ці дзяржавы і аказвае ўплыў рацыянальнымі (лічбы, факты) або эмацыянальнымі (вобразы, ацэнкі) 
сродкамі [10]. Палітычная ангажыраванасць, на нашу думку, сустракаецца значна часцей, чым акадэмічная бесстароннасць.

Назавём асноўныя функцыі загалоўка. Даследаваннем гэтага пытання займаліся такія навукоўцы, як Кастамарава В. Г., Лазарава Э. А., Мужаў В. С., Сыроў І. А., Нікіфарава Ж. А. і інш. Сярод мноства функцый асноўнымі, на нашу думку, з'яўляюцца інфармацыйная, рэкламная, экспрэсіўна-ацэначная і функцыя пераканання [11].

Загаловачны комплекс газеты «Звязда» характарызуецца напоўненасцю. У яго ўваходзяць амаль усе элементы, прадстаўленыя ў даследаваннях, на якія мы абапіраліся: рубрыка, загаловак, падзагаловак, лід і ўнутраныя загалоўкі.

Многія рубрыкі газеты з'яўляюцца пастаяннымі, але могуць узнікаць і новыя, каб аб'яднаць артыкулы на адну тэму. Наша даследаванне паказала, што газета «Звязда» мае наступныя пастаянныя рубрыкі: «Надзённае», «Сёння», «Інфармбюро», «Светагляд», «Люстэрка», «Суседзі», «Соцыум», «Напрыканцы». Хочацца звярнуць увагу і на іх лагічнае размяшчэнне (ад агульнага да прыватнага), і на іх сэнсавую і лексічную спалучальнасць.

Ёсць рубрыкі, якія сустракаюцца толькі ў некаторых выпусках газеты, напрыклад «Спорт-тайм», «Захапленне», «Камунальныя стасункі», «Аб’ектыў», «Ваша права». У час важных для краіны падзей, святаў, пасяджэнняў у газеце з'яўляюцца адпаведныя рубрыкі: 23 лютага - рубрыка «Плацдарм», 20 лютага - рубрыка «Да дня роднай мовы», VI Усебеларускі народны сход - рубрыкі «Перспектыва», «Вынікі і высновы», «Выступленні», 15 лютага - рубрыка «Водгулле» і г. д.

Можна таксама выдзяліць такі элемент загаловачнага комплексу, як падрубрыка, якая часта сустракаецца на старонках газеты. У рубрыцы «Сёння» ёсць падрубрыкі «Кадры», «Надвор'е», «На слыху». Падрубрыка ўдакладняе тэму артыкула на старонцы, дапамагае чытачу зразумець, што за матэрыял знаходзіцца перад ім. Напрыклад, падрубрыка «3 першых вуснаў» паказвае, што артыкул змяшчае інфармацыю $з$ асабістых сустрэч Прэзідэнта або з пасяджанняў, якія ён наведваў. Падрубрыкі «Крымінал», «Надвор'е», «Усміхнемся», «Новыя кнігі», «Грошы» больш ясна канкрэтызуюць тэму артыкулаў: злачынствы, прагноз надвор'я, анекдоты, навінкі кніжнай індустрыі, эканамічныя падзеі. «Нечакана», «Справа маладых», «Падрабязнасці» і іншыя не даюць вялікай канкрэтыкі, але праводзяць межы паміж артыкуламі адной рубрыкі. Падрубрыкі таксама мяняюцца ў залежнасці ад тэмы артыкулаў або могуць зусім адсутнічаць.

Найбольш распаўсюджанай структурай загаловачнага комплексу «Звязды» з’яўляецца наступная: рубрыка, падрубрыка, асноўны загаловак артыкула, падзагаловак, лід і некалькі ўнутраных загалоўкаў. Ёсць артыкулы, загалоўкі якіх даюцца на першай старонцы. Разам з загалоўкам там змяшчаюцца падзагаловак і лід, якія не паўтараюцца на старонцы артыкула. Замест іх перад тэкстам артыкула змяшчаецца наступнае: (Заканчэнне. Пачатак на 1-й стар.).

Прывядзём прыклад загаловачнага комплексу:

Рубрыка: «Надзённае».

Падрубрыка: «3 першых вуснаў».

Загаловак: «Трэба эфектыўна выкарыстоўваць фармат форуму для вырашэння найбольш актуальных пытанняў».

Падзагаловак: «Прэзідэнт Аляксандр Лукашэнка правёў нараду па пытаннях падрыхтоўкі і правядзення VI Усебеларускага народнага сходу».

Лід: «У нарадзе ўзялі ўдзел спікеры абедзвюх палат беларускага парламента, кіраўнікі Адміністрацыі і спраў Прэзідэнта, Мінскага гарвыканкама і Беларускага інстытута стратэгічных даследаванняў».

Унутраныя загалоўкі: «Узровень - высокі»; «Рашэнні - узважаныя»; «Аб’явілі байкот - байкатуйце»; «Мэта - зрабіць краіну лепшай».

Аналіз паказаў, што загаловачны комплекс названай рубрыкі «Надзённае» найчасцей мае менавіта такую структуру, як у прыведзеным прыкладзе. Калі прачытаць усе ўзроўні загалоўкаў ад назвы рубрыкі да ўнутраных загалоўкаў, змест матэрыялу становіцца цалкам зразумелы, калі трэба падрабязнасці - чытайце ўважліва ўвесь матэрыял. Яшчэ ў гэтай рубрыцы нярэдка сустракаецца ўрэзка на заліўцы, якая таксама мае сваю падрубрыку: «Каментарый у тэму». Тут коратка даецца каментарый спецыяліста па заяўленай тэме.

Прывядзём іншы прыклад загаловачнага комплексу.

Рубрыка: «Краіна здароўя».

Падрубрыка: «Скажыце, доктар...»

Загаловак: «Навошта нам абследавацца?»

Падзагаловак: «Якія віды раку выяўляе скрынінг».

Лід: «У Беларусі плануецца ўвядзенне яшчэ дзвюх праграм скрынінга раку - страўніка і лёгкага $[\ldots] »$.

Унутраных загалоўкаў матэрыял не мае, бо ўяўляе сабой інтэрв'ю, у якім функцыю структурнага члянення выконваюць пытанні да доктара, вылучаныя паўтлустым шрыфтам. Асабліва ўдала ў гэтым загаловачным комплексе выглядаюць падрубрыка і загаловак, якія ўтвараюць адно цэлае.

Зрэдку сустракаюцца інтрыгуючыя загалоўкі, якія не маюць падзагалоўка і ўнутраных загалоўкаў. Тады зразумець, пра што матэрыял, дапамагае ілюстрацыя, размешчаная зверху, пад загалоўкам. Так, матэрыял пад назвай «Жалезнае 
братэрства» аб супрацоўніцтве Беларусі і Кітая «маркіруе» фотаздымак 3 назвай індустрыяльнага парка і сцягамі дзвюх дзяржаў.

M. I. Шостак выдзяляе шэсць відаў загалоўкаў CMI ў залежнасці ад ступені інфарматыўнасці:

- загаловак-хроніка, які паведамляе аб падзеях і, як правіла, дубліруе навіну;

- загаловак-«бягучы радок», калі частка сказа выносіцца ў загаловак, далей сказ працягваецца ў тэксце;

- загаловак-рэзюмэ (рэзюмэ прамое, гульнёвае, іранічнае і інш.);

- загаловак-цытата, калі прыводзяцца словы вядомага суразмоўцы;

- загаловак-інтрыга, у якім ёсць мнагазначнасць, асацыяцыйныя сувязі;

- загаловак-«жахліўчык», які псіхалагічна напружвае чытача [12].

Прывядзём прыклады для кожнага віду загалоўкаў з лютаўскіх нумароў газеты «Звязда» за 2021 г.

1. Загаловак-хроніка («Вайскоўцы ў М'янме абвясцілі надзвычайнае становішча»; «ААЭ ўпершыню дадуць замежнікам магчымасць атрымаць грамадзянства»; «Бальніцы вяртаюцца да звыклага рэжыму»; «У Германіі пачаліся моцныя паводкі»).

2. Загаловак-«бягучы радок» («Год быў цяжкі, але прадуктыўны»).

3. Загаловак-рэзюмэ («Правілы “маскіроўкі”»; «Іран цікавіць усіх!..»; «У Эміратах ведаюць нашу згушчонку»).

4. Загаловак-цытата («Мы, як і раней, хочам быць астраўком бяспекі ў Еўропе, краінай, ад якой ідуць толькі мірныя ініцыятывы»; «Для мяне прырода - гэта абсалютны прыярытэт»; «Цаніце і шануйце тое, што маеце»).

5. Загаловак-інтрыга («Адзінаццаць смелых»; «Дапамог з рамонтам кватэры...»). осу»).

6. Загаловак-«жахліўчык» («Дзесяць гадоў ха-

3 пункту гледжання сінтаксісу асноўны загаловак найчасцей уяўляе сабой просты сказ. Загаловак і падзагаловак могуць быць адным сказам, 3 дапамогай памеру і гарнітуры шрыфту падзеленым на дзве часткі: ““Армейскі” капітал, маладзёжны ўзрост і грант для «студэнта года» (загаловак) абмяркоўвалі гродзенскія студэнты на сустрэчы з маладымі дэлегатамі IV Усебеларускага сходу» (падзагаловак). Яшчэ прыклад: «Паштальён на колах» (загаловак), «або Асаблівасці працы вясковага кур'ера» (падзагаловак).

У якасці загалоўка і падзагалоўка могуць выступаць два суседнія сказы з адной цытаты: «Моладзь гатова ехаць у глыбінку» (загаловак ). «Неабходна стварыць для іх камфортныя умовы» (падзагаловак). Шкада, што ў гэтым прыкладзе была абрана цытата са стылістычнай памылкай (ва ўжыванні займенніка). Такі від загалоўкаў падрабязна апісаны Л. С. Баннік [13].
Падзагаловак звычайна ўдакладняе асноўны загаловак, але бывае, што дадае інтрыгі: «Адзінаццаць смелых» (загаловак), «А яшчэ - таленавітых, крэатыўных, патрыятычных» (падзагаловак). У такім выпадку канкрэтыку ўносіць лід, з якога мы даведваемся, што гаворка ідзе пра 11 фіналістаў конкурсу «Студэнт года». Звычайна інтрыгуючы загаловачны комплекс мае рубрыка «Неасабісты суб'ектыў», у якой можна сустрэць, напрыклад, такі загаловак «Трасца 3 ферамонамі» 3 падзагалоўкам «або Колькі каштуе “суперпрыз на барабане"».

Гульня слоў, распаўсюджаная ў некаторых перыядычных выданнях [14], у «Звяздзе» сустракаецца рэдка: «Будаваць - не бедаваць», «Самая класная класная гадзіна!»

Найчасцей асноўны змест газетнага матэрыялу зразумелы, нават калі чытач праігнаруе назву рубрыкі: «Горкі малыя, праблемы вялікія» (загаловак), «Як дзецям пазбегнуць траўмаў зімой» (падзагаловак). У названым артыкуле ёсць урэзкі на каляровым фоне са сваімі назвамі «Забаронена» і «Правілы карыстання цюбінгам». Загаловачны комплекс разам з імі з'яўляецца вельмі інфарматыўным.

Уважлівы чытач, асабліва пастаянны чытач газеты, безумоўна, адзначыць якасна прадуманы загаловачны комплекс газеты, у якім кожны ўзровень прыўносіць сваё:

Рубрыка: «Таямніцы і адкрыцці».

Падрубрыка: «Каго мы бачым!».

Загаловак: «Удала схаваўся».

Падзагаловак: «Знайшлі від хамелеонаў, які лічыўся вымерлым»

Лід: «На Мадагаскары выявілі хамелеона [...]».

У газеце шырока распаўсюджаны ўнутраныя загалоўкі, яны разбіваюць буйныя па памеры матэрыялы і добра спалучаюцца паміж сабой. Напрыклад, матэрыял Людмілы Рублеўскай з назвай «Беларускія кнігі мусяць быць для нас прыярытэтам» мае наступныя падзагалоўкі: «Пра крызіс сусветнага кніжнага гандлю», «Пра аўтографcecii ў час пандэміi», «Пра электронныя кнігі», «Пра кнігу на роднай мове». Такія назвы тэматычна групіруюць тэкст, дапамагаюць вылучыць у ім асноўныя думкі, знайсці патрэбную інфармацыю.

Вядомы журналіст Шостак М. пісаў: «Сёння загалоўкі, як правіла, будуюцца па нетрадыцыйных для расійскай прэсы мадэлях. Доўгі час дамінуючыя прынцыпы, згодна 3 якімі загалоўкі павінны быць сціслымі і кароткімі, змяніліся на супрацьлеглыя. І наогул, наступіў час “аўтарскай свабоды”: у загалоўкі пайшлі абрэвіятуры, лічбы, імёны ўласныя, слэнг і размоўныя словы, іншамоўныя фрагменты» [9, с. 44]. У «Звяздзе» прыклады падобнай «аўтарскай свабоды» таксама можна знайсці, але не часта: «Настрой падорыць 
“пээфка» (загаловак), «Магілёўскія фотамастакі прапануюць далучыцца да традыцыі абменьвацца навагоднімі PF-паштоўкамі» (падзагаловак).

Зрэдку на старонках газеты можна сустрэць такі элемент загаловачнага комплексу, як шапка. Звычайна ён выкарыстоўваецца для аб'яднання адной тэмай невялікіх паведамленняў, каментарыяў. Напрыклад:

Рубрыка: «Размова па сутнасці».

Падрубрыка: «VI Усебеларускі народны сход». Шапка: «Праз прызму».

Шапка ў гэтым нумары аб'ядноўвае паведамленні трох чалавек: кіраўніка справамі Белавушскага сельскага савета Столінскага раёна Наталлі Касцюк, кіраўніка сялянска-фермерскай гаспадаркі «ДАК» Дзяржынскага раёна Дзмітрыя Крылова і старшыні СВК «Калгас "Радзіма"» Бялыніцкага раёна Аляксандра Лапацентава. У якасці назваў паведамленняў выкарыстоўваюцца цытаты, якія размешчаны на каляровай заліўцы са знакам «двукоссе».

Цікава было звярнуць увагу і на даўжыню загалоўкаў у газеце. Паводле нашых назіранняў, даўжыня асноўнага загалоўка ў газеце «Звязда» ў межах 4-10 слоў, найчасцей ад 4 да 6 слоў. Д. Е. Патрахова ў адным са сваіх артыкулаў, прысвечаных супастаўляльнаму аналізу аб'ёму і функцый загалоўка газетных матэрыялаў на базе рускамоўных, англамоўных і нямецкамоўных CMI, адзначае, што «ў сярэднім загалоўкі аб'ёмам ад 6 да 11 слоў з'яўляюцца найбольш распаўсюджанымі» для ўсіх моў, якія яна даследавала [15, с. 80]. Як бачым, газета «Звязда» імкнецца да лаканічнасці. Назвы рубрык найчасцей складаюцца 3 аднаго слова, падрубрык - з двух-трох. Загаловак - гэта 4-6 слоў, падзагаловак звычайна даўжэйшы. Унутраныя загалоўкі матэрыялаў таксама не бываюць буйнымі. Найбольшы па аб'ёме і адпаведна найбольш інфарматыўны элемент загаловачнага комплексу - гэта лід. Ён візуальна падкрэсліваецца, бо набраны паўтлустым шрыфтам 3 водступам управа, роўным шырыні абзацнага водступу ў артыкуле. 3 усіх элементаў загаловачнага комплексу рэдка сустракаецца шапка, аднак функцыя гэтага элемента не прадугледжвае яго абавязковую наяўнасць у кожным нумары.

Заключэнне. Стылістыка загаловачнага комплексу газеты «Звязда» нейтральная, і гэта ў поўнай меры адпавядае мэтаваму прызначэнню (грамадска-палітычнае выданне) і чытацкаму адрасу газеты (дарослы чытач, які цікавіцца грамадскім і палітычным жыццём краіны). Асноўная функцыя загаловачнага комплексу гэтай газеты - інфармацыйная. Экспрэсіўна-ацэначная, рэкламная і функцыя пераканання праяўляюцца значна менш.

У цэлым можна сказаць, што газета «Звязда»гэта сучаснае перыядычнае выданне, якое развіваецца згодна з сусветнымі тэндэнцыямі ў перыёдыцы, мае ўласную рэдакцыйную палітыку і фірменны стыль. Загалоўкі розных узроўняў, якія ўжывае газета на сваіх старонках, утвараюць гарманічны загаловачны комплекс.

\section{Спіс літаратуры}

1. Бугаева И. В., Сидорченко К. М. Параметры привлекательного для целевой аудитории заголовка СМИ // Известия Юго-Западного государственного университета. Сер. Лингвистика и педагогика. 2019. Т. 9, № 2(31). С. 41-48.

2. Гуревич С. М. Газета: вчера, сегодня, завтра: учеб. пособие для вузов. Режим доступа: http://evartist. narod.ru/text10/05.htm. Дата доступа: 28.08.2021.

3. Бессонов А. П. Газетный заголовок. Ленинград: Наука, 1958. 62 с.

4. Дрога М. А. Особенности заголовков в современной российской прессе (на материале новостей о Китае) // Современный дискурс-анализ. 2018. № 3 (20). Ч. 2. С. 233-238.

5. Муталиева 3. А., Добриева 3. И. Классификация заголовков // Lingua-universum. 2019. № 2. C. 44-46.

6. Зекиева П. М. Заголовочный комплекс в газете как макроструктура имени статьи // Вестник Адыгейского государственного университета. Сер. 2: Филология и искусствоведение. 2011. № 1. Режим доступа: https://cyberleninka.ru/article/n/zagolovochnyy-kompleks-v-gazete-kak-makrostruktura-imeni-stati. Дата доступа: 28.08.2021.

7. Фаткабрарова Ю. М. Структурно-семантическая характеристика кратких газетных сообщений: автореф. дис. ... канд. филол. наук: 10.02.01. М., 2007. 23 с.

8. Ляпун С. В. Заглавие как элемент текста и аспекты его изучения // Лингвистика текста. 1995. C. $124-126$. $180 \mathrm{c}$

9. Колесниченко А. В. Практическая журналистика: учеб. пособие. М.: Изд-во Моск. ун-та, 2008.

10. Агапова А. Н. Заголовок в современной русской прессе: эпистемический и прагматический аспекты: дис. ... канд. филол. наук: 10.02.01. Волгоград, 2011. 185 с.

11. Тертычный А. А. Заголовок - слово главное // Журналист. 2004. № 1 (21). С. 80-82.

12. Шостак М. Репортер: профессионализм и этика. Режим доступа: https://studfile.net/preview/ 7544532/page:27/. Дата доступа: 28.08.2021. 
13. Банник Л. С., Харченко Н. П. Заголовки-цитаты в современной газетной публицистике: тезисы. Владивосток: Дальневосточный университет, 2005. 190 с.

14. Вахтель Н. М. Речевые акты эмоционального воздействия в позиции газетного заголовка // Вестник Воронежского государственного университета. 2004. № 2. С. 47-49.

15. Потрахова Д. Е. Объем и функции заголовков статей в сопоставительном аспекте // Studia Germanica, Romanica et Comparatistica. 2020. T. 16. Вып. 2 (48). С. 80-92.

\section{References}

1. Bugaeva I. V., Sidorchenko K. M. Parameters of an attractive media title to the target audience. Izvestiya Yugo-Zapadnogo gosudarstvennogo universiteta [Proceedings of the Southwestern State University], series Linguistics and Pedagogy, 2019, vol. 9, no. 2 (31), pp. 41-48 (In Russian).

2. Gurevich S. M. Gazeta: vchera, segodnya, zavtra [Newspaper: yesterday, today, tomorrow]. Available at: http://evartist.narod.ru/text10/05.htm (accessed 28.08.2021).

3. Bessonov A. P. Gazetnyy zagolovok [Newspaper headline]. Leningrad, Nauka Publ., 1958. 62 p.

4. Droga M. A. Features of headlines in the modern Russian press (based on the material of news about China). Sovremennyy diskurs-analiz [Modern discourse analysis], 2018, no. 3 (20), parte 2, pp. 233-238 (In Russian).

5. Mutalieva Z. A., Dobrieva Z. I. Classification of headers. Lingua-universum, 2019, no. 2, pp. 44-46 (In Russian).

6. Zekieva P. M. Zagolovochnyy kompleks $v$ gazete kak makrostruktura imeni stat'i [The headline complex in the newspaper as a macrostructure of the article name]. Available at: https://cyberleninka.ru/article/n/zagolovochnyy-kompleks-v-gazete-kak-makrostruktura-imeni-stati (accessed 28.08.2021).

7. Fatkabrarova Yu. M. Strukturno-semanticheskaya kharakteristika kratkikh gazetnykh soobshcheniy: Avtoref. dis. ... kand. filol. nauk [Structural and semantic characteristics of brief newspaper reports. Abstract of thesis PhD (Philology)]. Moscow, 2007. 23 p.

8. Lyapun S. V. The title as an element of the text and aspects of its study. Lingvistika teksta [Text linguistics], 1995, pp. 124-126 (In Russian).

9. Kolesnichenko A. V. Prakticheskaya zhurnalistika [Practical journalism]. Moscow, Izd-vo Mosk. unta Publ., 2008. 180 p.

10. Agapova A. N. Zagolovok v sovremennoy russkoy presse: epistemicheskiy i pragmaticheskiy aspekty: Dis. ... kand. filol. nauk [The headline in the modern Russian press: epistemic and pragmatic aspects. Diss. PhD (Philology)]. Volgograd, 2011. 185 p.

11. Tertychnyy A. A. The title is the main word. Zhurnalist [Journalist], 2004, no. 1 (21), pp. 80-82 (In Russian).

12. Shostak M. Reporter: professionalizm i etika [Reporter: Professionalism and ethics]. Available at: https://studfile.net/preview/7544532/page:27/ (accessed 28.08.2021).

13. Bannik L. S. Harchenko N. P. Zagolovki-tsitaty $v$ sovremennoy gazetnoy publitsistike [Headlinesquotes in modern newspaper journalism]. Vladivostok, Dal'nevostochnyy universitet Publ., 2005. 190 p.

14. Vakhtel' N. M. Speech acts of emotional impact in the position of a newspaper headline. Vestnik Voronezhskogo gosudarstvennogo universiteta [Bulletin of the Voronezh State University], 2004, no. 2, pp. 47-49 (In Russian).

15. Potrakhova D. E. The scope and functions of the headings of articles in the comparative aspect. Studia Germanica, Romanica et Comparatistica, 2020, vol. 16, no. 2 (48), pp. 80-92 (In Russian).

\section{Звесткі пра аўтараў}

Зылевіч Дзіна Паўлаўна - кандыдат філалагічных навук, дацэнт, дацэнт кафедры рэдакцыйнавыдавецкіх тэхналогій. Беларускі дзяржаўны тэхналагічны ўніверсітэт (220006, г. Мінск, вул. Свярдлова, 13а, Рэспубліка Беларусь). E-mail: din-a@tut.by

Канапацкая Настасся Уладзіславаўна - студэнтка. Беларускі дзяржаўны тэхналагічны ўніверсітэт (220006, г. Мінск, вул. Свярдлова, 13а, Рэспубліка Беларусь). E-mail: nastassiakon@gmail.com

\section{Information about the authors}

Zylevich Dina Pavlovna - PhD (Philology), Assistant Professor, Associate Professor, the Department of Editorial and Publishing Technologies. Belarusian State Technological University (13a, Sverdlova str., 220006, Minsk, Republic of Belarus).E-mail: din-a@tut.by

Konopatskaya Anastasiya Vladislavovna - student. Belarusian State Technological University (13a, Sverdlova str., 220006, Minsk, Republic of Belarus). E-mail: nastassiakon@gmail.com 